УДК 37.091.12:005.963:37.013.83

DOI:

Володимир Піддячий, кандидат педагогічних наук, стариий науковий співробітник відділу андрагогіки Інституту педагогічної освіти і освіти дорослих імені Івана Зязюна НАПН Украӥни

\title{
МЕТОДОЛОГІЧНІ ЗАСАДИ РОЗВИТКУ АНДРАГОГІЧНОЇ КОМПЕТЕНТНОСТІ ПЕДАГОГІВ У ЗАКЛАДАХ ВИЩОЇ ОСВІТИ
}

У статті розглянуто методологічні засади розвитку андрагогічної компетентності педагогів у закладах вищьої освіти. Вказано, щзо розвиток андрагогічної компетентності педагогів спрямований на підвищення готовності до роботи з дорослою аудиторією. Зазначено, изо використання фундаментальної, загальнонаукової та конкретнонаукової методології є основою для наукового обтрунтування результатів дослідження проблеми розвитку андрагогічної компетентності педагогів, визначення наукових принципів і підходів, на основі яких воно базується, а також здійснення вибору пізнавальних засобів, методів і прийомів.

Ключові слова: методологія; розвиток; андрагогічна компетентність; педагог; заклад вищоїосвіти. Jim. 16.

Volodymyr Piddyachiy, Ph.D.(Pedagogy), Senior Researcher of the Andragogy Department, Ivan Zyazyun Institute of Pedagogical Education and Adult Education National Academy of Pedagogical Sciences of Ukraine

\section{METHODOLOGICAL FUNDAMENTALS OF DEVELOPING ANDRAGOGICAL COMPETENCE OF TEACHERS IN HIGHER EDUCATIONAL ESTABLISHMENTS}

The methodological bases of developing an andragogical competence of teachers in higher educational establishments are considered in the article. It is noted that in the conditions of dynamic socio-economic changes and gradual transition to reproductive resources, transformation and redistribution of different types of capital there is a demand for moral and socio-professionally developed personality who is able to solve problems of different levels of complexity.

It is indicated that the development of andragogical competence of teachers in higher educational establishments is aimed at increasing readiness to work with adult audiences, which includes the ability to identify the educational needs and requests, take into account the motivation, learning, group dynamics of adult audiences, apply moderation, facilitation, mentoring the audience to interaction during learning, to determine the learning outcomes, to encourage the audience to reflect.

It is noted that the use of fundamental methodology (the principle of dialectics, determinism, and isomorphism) contributes to understanding the essence of the development of andragogical competence of teachers and its purpose. It is pointed out that the methodological basis of research at the level of general scientific methodology are laws, principles, general logical and empirical methods that reveal the patterns of development of andragogical competence of teachers in higher educational establishments. It is noted that they allow agreeing on the conceptual apparatus, to determine the factors, preconditions, as well as approaches aimed at solving the research problem. The essence of historical, terminological and cognitive principles, as well as activity, an informational, axiological (value), competence, individual and andragogical approach to the study of the development of andragogical competence of teachers is revealed. It is noted that the methodological basis of the research at the specific scientific level is the concept of pedagogical skill of I. Zyazyun. Based on it, the emphasis is put on the importance for the teacher: 1) to carry out lifelong learning; 2) to update knowledge, skills and abilities; 3) to develop professional and personal qualities; 4) to gain new experience; 5) to master the scientific methodology. education

Keywords: methodology; development; andragogical competence; a teacher; an institution of higher

П остановка проблеми. Поступовий перехід до відтворювальних видів ресурсів та динамічні соціальноекономічні зміни, викликані трансформацією і перерозподілом різних видів капіталу, спонукають до аналізу проблем, пов'язаних із розбудовою українського суспільства і держави. У сучасних умовах є запит на моральну та соціальнопрофесійно розвинену особистість, здатну розв'язувати проблеми різного рівня складності $[13,108]$. Особливої уваги потребують проблеми, що пов'язані із підготовкою компетентних фахівців, здатних до самонавчання, самовиховання ісаморозвиткузметоюформуванням загальнолюдських цінностей іякостей, оволодіння сучасними засобами, формами та методами роботи $[14,11]$. Основними чинниками, які це обумовили, $є:$ 1) природне старіння населення та демографічна криза; 


\section{МЕТОДОЛОГІЧНІ ЗАСАДИ РОЗВИТКУ АНДРАГОГІЧНОЇ КОМПЕТЕНТНОСТІ ПЕДАГОГІВ У ЗАКЛАДАХ ВИЩОЇ ОСВІТИ}

2) зовнішня трудова міграція; 3) дисбаланс на ринку праці; 4) недостатній рівень компетентності людей старших 45 років для працевлаштування і залучення до соціальних процесів [5, 7-8].

Окреслені проблеми зумовлюють важливість освіти впродовж життя, складовою якої є освіта дорослого населення.

Аналіз досліджень. Упродовж дослідження проблеми розвитку андрагогічної компетентності педагогів у закладах вищої освіти, з метою визначення його методологічних засад, було проаналізовано і узагальнено праці вітчизняних та зарубіжних вчених (С. Гончаренко, І. Зязюна, О. Крушельницької, Н. Кушнаренко, А. Леонтьева, В. Лунячек, Л. Набока, В. Пуцова, М. Смирнова, В. Шейко та ін.).

Науковці стверджують, що визначення методологічних основ дослідження: 1) сприятиме осмисленню мети, сутності та закономірностей розвитку андрагогічної компетентності педагогів; 2) дасть змогу узгодити понятійний апарат, визначити чинники, передумови, а також підходи, спрямовані на розв'язання проблеми дослідження; 3) допоможе встановити пріоритетні напрями розвитку андрагогічної компетентності педагогів.

Мета статті - дослідити методологічні засади розвитку андрагогічної компетентності педагогів у закладах вищої освіти.

Виклад основного матеріалу. У зв'язку зі зростанням ролі андрагогіки як наукового напряму в системі педагогічного знання та запитами науки і практики щодо необхідності професійної перепідготовки дорослих важливого значення набувають питання, пов'язані з розвитком андрагогічної компетентності педагогів.

Андрагогічну компетентність педагогів ми розглядаємо як готовність до роботи з дорослою аудиторією, що передбачає вміння визначати освітні потреби і запити, ураховувати особливості мотивації, навчання, групової динаміки дорослої аудиторії, застосовувати технології модерації, фасилітації, менторства, залучати аудиторію до інтерактивної взаємодії впродовж навчання, визначати результати навчання, спонукати аудиторію до рефлексії [9].

Методологічні засади розвитку андрагогічної компетентності педагогів у закладах вищої освіти розглядаємо як сукупність наукових принципів і підходів, на основі яких базується його дослідження та проводиться вибір пізнавальних засобів, методів і прийомів. Її застосовуємо на трьох рівнях:

- фундаментальному (філософському). Його основа - філософські знання, що $є$ підгрунтям для дослідження розвитку андрагогічної компетентності педагогів у закладах вищої освіти. Вони мають науковий характер, оскільки виражають спрямованість на досягнення об'єктивної істини. Водночас, їм притаманні ціннісне спрямування, що виражається у визначенні мети діяльності та світоглядних основ, які не завжди можуть мати логічне обгрунтування. Філософські знання $\epsilon$ інтегративними, оскільки філософія досліджує Всесвіт. Вони розкривають зв'язок світоглядних уявлень про навколишній світ, суспільство та місце особистості в ньому 3 педагогічною дійсністю. У цьому контексті філософія і педагогіка $є$ взаємопов'язаними. Фундаментальна (філософська) методологія сприяє осмисленню сутності розвитку андрагогічної компетентності педагогів та його мети. Впродовж дослідження цього явища на рівні фундаментальної методології, ми застосовували принципи: 1) діалектики, згідно з яким розвиток явищ дійсності $є$ взаємозумовленим i суперечливим; 2) детермінізму - полягає в об'єктивній причинній зумовленості явищ; 3 ) ізоморфізму - відображає відношення об'єктів, що відбивають тотожність їх побудови та ін. [16, 57-59]:

- загальнонауковому. Його змістом є закони, принципи, загально логічні та емпіричні методи, теоретичні концепції, що розкривають закономірності розвитку андрагогічної компетентності педагогів у закладах вищої освіти. Вони дали змогу узгодити понятійний апарат, визначити чинники, передумови та підходи, спрямовані на розв'язання проблеми дослідження. Для дослідження розвитку андрагогічної компетентності педагогів у закладах вищої освіти на рівні загальнонаукової методології ми застосовували: 1) історичний, термінологічний та когнітивний принципи; 2) діяльнісний, інформаційний, аксіологічний (ціннісний), компетентнісний, індивідуальний і андрагогічний підходи $[1,88]$.

Історичний принцип використаний 3 метою дослідження виникнення та еволюції поняття андрагогічної компетентності педагогів. Це пов'язано $з$ тим, що перш ніж вивчати сучасний стан необхідно проаналізувати генезис та розвиток предмета дослідження та його основні категорії. Адже найкращі і прогресивні знання щодо поняття андрагогічної компетентності педагогів накопичені впродовж певного історичного періоду модернізуються і стають новими, набуваючи смислів і дієвості на сучасному рівні. Водночас вони перебувають у діалектичній взаємодії. Застосування історичного підходу дало змогу дослідити виникнення і еволюцію поняття андрагогічної компетентності 


\section{МЕТОДОЛОГІЧНІ ЗАСАДИ РОЗВИТКУ АНДРАГОГІЧНОЇ КОМПЕТЕНТНОСТІ ПЕДАГОГІВ У ЗАКЛАДАХ ВИЩОЇ ОСВІТИ}

педагогів 3 метою виявлення закономірностей та суперечностей, а також зовнішніх і внутрішніх зв'язків.

Термінологічний принцип застосований з метою вивчення історії ключових понять дослідження, уточнення змісту та обсягу, встановлення взаємозв' язку і субординації, визначення їхнього місця в понятійному апараті дослідження розвитку андрагогічної компетентності педагогів. Для забезпечення термінологічного принципу використано методи термінологічного аналізу та операціоналізації понять. Формування структури і змісту поняттєвого апарату дослідження базувалось на довідковій та спеціальній літературі. Обсяг і зміст понять визначались через родову ознаку і найближчу видову відмінність. При визначенні понять дотримано правила: 1) розмірності, відповідно до якого обсяг поняття, що визначається, має відповідати обсягу поняття, яке визначає; 2) правило неповторюваності - нове поняття не повинно бути тавтологічним; 3 ) чіткості і однозначності.

Діяльнісний підхід застосований з метою розгляду педагога як активного суб'єкта взаємодії. В його основі є предметна діяльність педагога, що спрямована на розвиток андрагогічної компетентності. Вона характеризується активністю й динамічністю взаємодії із зовнішнім середовищем, задоволенням потреб та досягненням свідомо поставлених цілей. Професійно удосконалюючись, педагог стає суб'єктом свого розвитку [12, 140-146] і змінює довкілля. У контексті поглядів О. Леонтьєва розвиток андрагогічної компетентності забезпечується через систему діяльностей, що змінюють одна одну $[7,181]$. Одиницею діяльності є дія. Їй властива така структура: 1) потреба; 2) мотив; 3) ціль; 4) об’єкт спрямованості; 5) набір операцій і образів для реалізації [3, 9]. Розвиток андрагогічної компетентності педагогів $\epsilon$ діяльністю, що розширює його систему знань, норм і правил професійної діяльності, а також формує психологічний досвід.

Інформаційний підхід застосований з метою виявлення найхарактерніших інформаційних аспектів розвитку андрагогічної компетентності педагогів. Його основою є принцип інформаційності. У контексті нашого дослідження він передбачає, що розвиток андрагогічної компетентності педагогів у закладах вищої освіти має інформаційну основу, яка є носієм смислу всіх процесів, пов'язаних із професійною діяльністю. Взаємозв'язки педагога із суб'єктами професійної взаємодії мають інформаційний характер, оскільки пов'язані зі створенням, накопиченням, обміном та використанням інформації. Застосування інформаційного підходу дало змогу дослідити якості, загальні властивості та закономірності, важливі для розуміння сутності розвитку андрагогічної компетентності педагогів у закладах вищої освіти.

Аксіологічний (ціннісний) підхід застосований 3 метою визначення основних загальнолюдських (добро, краса, істина, справедливість і сім'я), національних (патріотизм, державний суверенітет, національна безпека та національна культура) та європейських (природні права людини, демократія та верховенство права) цінностей, що становлять основу андрагогічної компетентності педагогів і здатні задовольнити його особистісні потреби та очікування суспільства, у якому він живе і активно працює.

Компетентнісний підхід застосований з метою спрямування розвитку андрагогічної компетентності педагогів на набуття спеціальних знань, умінь, навичок, способів мислення, поглядів, цінностей та інших особистих якостей, що визначають його здатність успішно соціалізуватися, проводити професійну або подальшу навчальну діяльність [2; $11,145]$. Він сприяв окресленню основних вимог до андрагогічної компетентності педагогів. Серед них можна виокремити: 1) здатність успішно розв'язувати професійні завдання, пов'язані із навчанням, вихованням і розвитком особистості дорослого суб'єкта учіння; 2) сформованість мотивації до професійної діяльності; 3) досягнення майстерності на засадах розвитку професійно важливих якостей, спираючись на норми та еталони професії.

Індивідуальний підхід застосований з метою врахування індивідуальних особливостей педагога та умов професійного середовища впродовж розвитку андрагогічної компетентності. Його використання сприяло: 1) вивченню діяльності й індивідуальних особливостей особистості педагога; 2) визначенню найближчих конкретних і віддалених цілей та завдань професійного розвитку; 3 ) формуванню у педагога професійно важливих якостей; 4) застосуванню оптимальних форм, методів і засобів навчання з урахуванням особливостей професійної діяльності; 5) визначенню і обліку труднощів, помилок, і недоліків.

Андрагогічний підхід застосований $з$ метою виокремлення принципів розвитку андрагогічної компетентності педагогів: 1) пріоритет самостійності навчання і спільної діяльності; 2) спирання на психологічний досвід; 3) індивідуалізацію, системність, елективність та контактність навчання, актуалізація його результатів; 4) розвиток освітніх потреб; 5) усвідомлення навчання $[15,17$ 


\section{МЕТОДОЛОГІЧНІ ЗАСАДИ РОЗВИТКУ АНДРАГОГІЧНОӤ КОМПЕТЕНТНОСТІ ПЕДАГОГІВ У ЗАКЛАДАХ ВИЩОЇ ОСВІТИ}

18]. Це сприяло виявленню умов його ефективного здійснення: 1) орієнтація на особистісні і професійні потреби; 2) об'єктивне оцінювання й переосмислення професійних дій; 3) спонукання до активності; 4) застосування андрагогічної компетентності у професійній діяльності [8].

- конкретно-науковому. Його змістом $€$ загальновизнані концепції провідних учених, а також сукупність методів, принципів і процедур дослідження, які застосовуються у певній галузі науки. Вони поєднують собі елементи фундаментальної і загальнонаукової методології [6, 57-65; 1, 88, 281-282].

Методологічною основою дослідження розвитку андрагогічної компетентності педагогів на конкретно-науковому рівні є концепція педагогічної майстерності І. Зязюна. Згідно з нею, педагогу впродовж розвитку андрагогічної компетентності, важливо: 1) здійснювати неперервне навчання; 2) оновлювати знання, уміння та навички; 3) розвивати професійноособистісні якості; 4) отримувати новий досвід; $5)$ опановувати наукову методологію. У зазначеному контексті серед основних напрямів професійно-педагогічного розвитку виокремлюємо:

1) світоглядну підготовку, що передбачає: a) розвиток національних, європейських та загальнолюдських цінностей; б) усвідомлення духовної і біоенергетичної сутності людини; в) визнання важливості освіти впродовж життя; г) вивчення концепціїсталого розвитку; д) гуманістичне ставлення до суб'єктів учіння тощо;

2) формування здатності до метапредметного осмислення навчального матеріалу та опанування сучасних методів наукового пізнання;

3) удосконалення інформаційно-цифрової та іншомовної комунікативної компетентності;

4) формування готовності до ефективної та творчої організації учіння;

5) удосконалення рівня педагогічної майстерності, яка передбачає володіння спеціальними професійними якостями і універсалізмом [4, 88-89; 10, 104].

Висновки. Розвиток андрагогічної компетентності педагогів сприятиме подоланню труднощів, що пов'язані із підготовкою та перепідготовкою дорослих фахівців, оскільки підвищуватиме якість їхьої роботи з дорослою аудиторією на засадах удосконалення умінь: 1) визначати освітні потреби і запити; 2) ураховувати особливості мотивації навчання та групової динаміки дорослої аудиторії; 3) застосовувати технології модерації, фасилітації, менторства; 4) залучати аудиторію до інтерактивної взаємодії впродовж навчання; 5) визначати результати навчання; 6) спонукати аудиторію до рефлексії.
Використання фундаментальної (принцип діалектики, детермінізму, ізоморфізму), загальнонаукової (історичний, термінологічнийтакогнітивний принципи; діяльнісний, інформаційний, аксіологічний (ціннісний), компетентнісний, індивідуальний, андрагогічний підходи) та конкретно-наукової (концепція педагогічної майстерності I. Зязюна) методології дало змогу науково обгрунтувати результати дослідження проблеми розвитку андрагогічної компетентності педагогів, визначити наукові принципи і підходи, а також здійснити вибір пізнавальних засобів, методів і прийомів.

До перспектив подальших досліджень відносимо аналіз тенденцій розвитку андрагогічної компетентності педагогів у закладах вищої освіти.

\section{ЛІТЕРАТУРА}

1. Гончаренко С. У. Педагогічні дослідження. Методологічні поради молодим науковиям. Київ; Вінниця, 2010.308 c.

2. Закон “Про освіту”. Відомості Верховної Ради, 2017. № 38-39. 380 c.

3. Зязюн І. А. Історичні витоки психологічної педагогіки. Рідна школа, 2013. №11. С. 3-12.

4. Зязюн I. А. Педагогічна професія в контексті двох парадоксів. Професійна освіта: педагогіка психологія : пол.-укр., укр.-пол. щоорічник. Вип. XIV, 2012. C. 88-89.

5. Колишко Р., Лазоренко О. Якою має бути політика навчання дорослих в Україні? Аналітичний звіт. Київ, $2018.52 \mathrm{c}$.

6. Крушельницька О.В. Методологія та організація наукових досліджень. Київ: Кондор, 2006. 206 с.

7. Леонтьев А. А. Слово в речевой деятельности. Некоторые проблемы общей теории речевой деятельности. Москва : Наука, 1965. 245 с.

8. Лунячек В. Е., Смирнова М. Є. Формування управлінською компетентності керівника загальноосвітнього навчального закладу на засадах андрагогіки. Теорія та методика управління освітою, 2010. №3. URL: http://umo.edu.ua/images/content/ nashi_vydanya/metod_upr_osvit/v_3/19.pdf (дата звернення: 23.10.2020).

9. Наказ МОН "Про затвердження Орієнтовної навчальної програми підготовки тренерів для навчання педагогічних працівників, які навчатимуть учнів перших класів у 2018/2019 i 2019/2020 навчальних роках" (2018). URL: zakon.rada.gov.ua/rada/show/v0097729-18\#Text (дата звернення: 23.10.2020).

10. Піддячий В. М. Дослідження сутності професіоналізації педагогів. Профорієнтація: стан $і$ перспективи розвитку: збірник матеріалів X ювілейних Всеукраїнських психолого-педагогічних читань, присвячених пам'яті доктора педагогічних наук, професора Федоришина Бориса Олексійовича. Київ: Ін-т пед. освіти і освіти дорослих імені І. Зязюна НАПН України, 2020. $147 \mathrm{c.}$

11. Піддячий В.М. Професійні параметри майбутнього вчителя. Наукові записки. Київ: Вид-во 


\section{МЕТОДОЛОГІЧНІ ЗАСАДИ РОЗВИТКУ АНДРАГОГІЧНОЇ КОМПЕТЕНТНОСТІ ПЕДАГОГІВ У ЗАКЛАДАХ ВИЩОЇ ОСВІТИ}

НПУ імені М.П. Драгоманова. Вип. СХІІІ (113), 2013, С. 156-165. URL: lib.iitta.gov.ua/8963/1/5.pdf (дата звернення: 23.10.2020).

12. Піддячий В.М. Професійні самоосвіта та самовиховання майбутнього вчителя. Наукові записки. Київ: Вид-во НПУ імені М.П. Драгоманова. Вип. СXII (112), 2013, C. 140-146. URL: lib.iitta.gov.ua/11406/1/7.pdf (дата звернення: 23.10.2020).

13. Піддячий М. І. Соціально-професійний розвиток: компетентності старшокласників та студентів. Розвиток сучасної освіти і науки: результати, проблеми, перспективи. Том VII: Ідентичність і свобода в освіті та науці. Конін - Ужгород - Бєльско-Бяла - Київ: Посвіт, 2019. URL: lib.iitta.gov.ua/718203/1/Піддячий \%20M.I._Тези_27.11.2019.pdf(дата звернення: 23.10.2020).

14. Піддячий М. I. Теоретико-методичні засади підготовки старшокласників до професійної діяльності в умовах профільного навчання: дис. ... д-ра пед. наук: 13.00.02. Ін-т педагогіки НАПН України. Київ, 2010. URL: ht tp s://1ib.iitta.gov.ua/ $717244 / 1 /$ Піддячий\%20M.I._ДисДоктор_Довідки_Відзиви_2010.pdf (дата звернення: 23.10.2020).

15. Пуцов В. І., Набока Л. Я. Особливості навчання дорослої людини. Київ: ЦІПО АПН України, 2004. 56 с

16. Шейко В.М., Кушнаренко Н.М. Організація та методика науково-дослідницької діяльності. Київ: Знання, 2006. 295 с.

\section{REFERENCES}

1. Honcharenko, S. U. (2010). Pedahohichni doslidzhennia. Metodolohichni porady molodym naukovtsiam [Pedagogical research. Methodological advice for young scientists]. Kyiv; Vinnytsia, 308 p. [in Ukrainian].

2. Zakon "Pro osvitu" (2017). [Law "On Education"]. Information of the Verkhovna Rada, No. 38-39, 380 p. [in Ukrainian].

3. Ziaziun, I. A. (2013). Istorychni vytoky psykholohichnoi pedahohiky [Historical origins of psychological pedagogy]. Native school, No. 11, pp. 3 12. [in Ukrainian].

4. Ziaziun, I. A. (2012). Pedahohichna profesiia v konteksti dvokh paradoksiv [The teaching profession in the context of two paradoxes]. Vocational education: pedagogy and psychology: pol.-ukr., kr.-pol. yearbook, pp. 88-89. [in Ukrainian].

5. Kolyshko, R. \& Lazorenko, O. (2018). Yakoiu maie buty polityka navchannia doroslykh $\mathrm{v}$ Ukraini? Analitychnyi zvit [What should be the policy of adult education in Ukraine? Analytical report]. Kyiv, 52 p. [in Ukrainian].

6. Krushelnytska, O.V. (2006). Metodolohiia ta orhanizatsiia naukovykh doslidzhen [Methodology and organization of scientific research]. Kyiv, 206 p. [in Ukrainian].

7. Leontev, A. A. (1965). Slovo v rechevoj deyatelnosti. Nekotorye problemy obshchej teorii rechevoj deyatelnosti [Word in speech activity. Some problems of the general theory of speech activity]. Moscov, 245 p. [in Russian].

8. Luniachek, V. E. \& Smyrnova, M. Ye. (2010). Formuvannia upravlinskoiu kompetentnosti kerivnyka zahalnoosvitnoho navchalnoho zakladu na zasadakh andrahohiky [Formation of managerial competence of the head of a secondary school on the basis of andragogy]. Theory and methods of education management, No.3. [in Ukrainian].

9. Nakaz MON "Pro zatverdzhennia Oriientovnoi navchalnoi prohramy pidhotovky treneriv dlia navchannia pedahohichnykh pratsivnykiv, yaki navchatymut uchniv pershykh klasiv u 2018/2019 i 2019/2020 navchalnykh rokakh" (2018). [Order of the Ministry of Education and Science "On approval of the Indicative curriculum for the training of trainers for the training of teachers who will teach first-graders in the 2018/2019 and 2019/2020 academic years"]. Available at: zakon.rada.gov.ua/rada/show/ v0097729-18\#Text [in Ukrainian].

10. Piddiachyi, V. M. (2020). Doslidzhennia sutnosti profesionalizatsii pedahohiv [Research of the essence of professionalization of teachers]. Career guidance: state and prospects of development: a collection of materials of the 10th anniversary All-Ukrainian psychological and pedagogical readings dedicated to the memory of Doctor of Pedagogical Sciences, Professor Borys Oleksiyovych Fedoryshyn. Kyiv: Ivan Ziaziun Institute of Pedagogical Education and Adult Education, 147 p. [in Ukrainian].

11. Piddiachyi, V.M. (2013). Profesiini parametry maibutnoho vchytelia [Professional parameters of the future teacher]. Scientific notes. Kyiv: Vyd-vo NPU imeni M.P. Drahomanova. Vol. CXIII (113), pp. 156-165. Available at: lib.iitta.gov.ua/8963/1/5.pdf [in Ukrainian].

12. Piddiachyi, V.M. (2013). Profesiini samoosvita ta samovykhovannia maibutnoho vchytelia. Scientific notes [Professional self-education and self-education of the future teacher]. Kyiv: Vyd-vo NPU imeni M.P. Drahomanova. Vol. CXII (112), pp. 140-146. Available at: lib.iitta.gov.ua/ 11406/1/7.pdf. [in Ukrainian].

13. Piddiachyi, M. I. (2019). Sotsialno-profesiinyi rozvytok: kompetentnosti starshoklasnykiv ta studentiv [Socio-professional development: competencies of high school and university students]. Development of modern education and science: results, problems, prospects. Volume VII: Identity and Freedom in Education and Science. Konin-Uzhhorod-Bielsko-Biala-Kyiv: Posvit. Available at: lib.iitta.gov.ua/718203/1/Piddiachyi \%20M.I._Tezy_27.11.2019.pdf. [in Ukrainian].

14. Piddiachyi, M. I. (2010). Teoretyko-metodychni zasady pidhotovky starshoklasnykiv do profesiinoi diialnosti v umovakh profilnoho navchannia [Theoretical and methodical bases of preparation of senior pupils for professional activity in the conditions of profile training]. Doctorjs thesis. Kyiv. Available at: https://lib.iitta.gov.ua/ 717244/1/Piddiachyi \%20M.I. _DysDoktor_Dovidky _Vidzyvy_2010.pdf. [in Ukrainian].

15. Putsov, V. I. \& Naboka, L. Ya. (2004). Osoblyvosti navchannia dorosloi liudyny [Features of adult learning]. Kyiv, 56 p. [in Ukrainian].

16. Sheiko, V.M. \& Kushnarenko, N.M. (2006). Orhanizatsiia ta metodyka naukovo-doslidnytskoi diialnosti [Organization and methods of research activities]. Kyiv, 295 p. [in Ukrainian].

Стаття надійшла до редакції 26.08.2020 